\title{
Capital Flows, Trade in Widgets and the Exchange Rate
}

\section{Irfan ul Haque*}

The economics profession has recently started to give increased recognition to the need for restraining capital movements and exercising greater care in opening up capital accounts in developing countries. ${ }^{1}$ This is a significant development, for, not long ago, unfettered flow of capital across countries was being hailed as a means for improving global efficiency and promoting world welfare. At its annual meetings in 1997, the IMF had pushed to incorporate capital account convertibility into its Articles of Agreement. However, the gravity of the East Asian crisis drove home the dangers inherent in premature deregulation of financial markets and freeing of capital movements, at least as far as developing countries are concerned.

The proponents of caution in the opening up of capital accounts base their case essentially on the imperfections of capital markets or market failures. In the presence of asymmetric information between borrowers and lenders, moral hazard in managing other people's money, and situations where the risk facing an individual decision-maker is lower than the social risk, a free market is unlikely to yield optimal outcomes. As Bhagwati (1998) has put it, trade in widgets is not the same thing as free movement of capital. The latter suffers from "panics and manias" which can suddenly and quickly more than offset any efficiency gains brought about by the free flow of capital. Bhagwati notes:

"Each time a crisis related to capital inflows hits a country, it typically goes through the wringer. The debt crisis of the 1980s cost South America a decade of growth. The Mexicans, who were vastly overexposed through shortterm inflows, were devastated in 1994. The Asian economies of Thailand, Indonesia, and South Korea, all heavily burdened with short-term debt, went into a tailspin ... drastically lowering their growth rates.” (p. 8)

This note attempts to extend the case for moving slowly and prudently also to trade liberalisation. It makes basically three points. First, it attempts to show that for both ideological and economic reasons, the opening up of the capital account and the freeing of capital movements are

\footnotetext{
* The author is currently consultant to G-24, an inter-governmental group, representing the interests of the developing countries at the IMF and the World Bank.

${ }^{1}$ The list of mainstream economists subscribing to this view is long and impressive. They include Bhagwati (1998), Krugman (1998), Sachs (1998), Stiglitz (1998), and Rodrik (1998), among others.
} 
in fact intimately linked to the measures to liberalise trade. Thus, it may be difficult to institute a regime of free trade while the capital account is closely regulated. Indeed, and this is the second point, market imperfections that are put forward as a reason for controlling capital movements and keeping the capital account closed also provide grounds for trade policy interventions. And, third, whether it is trade liberalisation or freeing capital movements, the villain in the piece is the exchange rate management.

The benefits that open trade regimes and free capital mobility promise are more likely to be realised under stable exchange rates, but they also create conditions where exchange rates tend to be unstable. There is evidence that within a liberal trading environment, trade deficits rise, external borrowing is increased, and exchange rates become vulnerable, at least as far as developing countries are concerned. It is typically the fear of impending devaluation that triggers capital outflows, which ultimately leads to currency crises. Unless some satisfactory means are found to stabilise exchange rates, moves towards market liberalisation and deregulation will continue to threaten economic stability and growth. Whether stabilising exchange rates is feasible or desirable is, therefore, an important issue to consider in the redesign of the international financial system. The following three sections elaborate on these points. The final section summarises the conclusions.

\section{Mutual Dependence of Trade and Capital Account Liberalisation}

Over the last two decades, market liberalism has swept virtually the entire world. Government interventions and regulations that hinder the free functioning of the market have come under attack. The state has come to be regarded as generally unfit to own or manage industrial enterprises or even public utilities. Market signals, undistorted by public policy, are viewed as the supreme disciplining force to guide consumers and producers towards optimal choices. The removal of controls and regulations that interfere with the market's free functioning and privatisation of public enterprises have become prominent in the political agenda of industrial as well as many developing countries. Market reforms have been central to the availability of financing from the international financial institutions, notably, the IMF and the World Bank.

Thus, the moves to liberalise trade and open up capital accounts in developing countries can be seen to be driven by the same political and ideological forces. In a number of countries, in fact, the deregulation of financial markets and the removal of capital controls were pursued more aggressively than trade liberalisation simply because asset-owners, who exercise considerable influence on policy, benefited from them. While trade 
liberalisation threatens the rents that industry enjoys from protection, free capital mobility makes it easier to spirit away financial gains to foreign sanctuaries. In Pakistan, for example, local industries resisted (in many cases, successfully) the attempts at trade liberalisation, but the removal of restrictions over rupee convertibility and the opening of foreign-currency accounts remained highly popular. ${ }^{2}$

The ideological shift aside, there are also solid economic reasons why policies governing trade cannot be sharply separated from those governing capital movements. In theory, the removal of trade barriers is expected to yield significant efficiency gains for it allows the factors of production to get reallocated to fields of activity where the country has a comparative advantage. The argument runs basically along the following lines. Tariffs and other forms of trade restrictions, by raising domestic prices of traded products, discourage their import and encourage their domestic production. However, the impact is not confined just to imports. Because import restrictions allow the country to maintain an appreciated currency, they tend also to discourage exports.

This line of reasoning leads to a powerful economic proposition: protection, because it tends to reduce both imports and exports, is not particularly effective in lowering trade deficits. The actual experience indeed shows that import barriers by themselves are rarely sufficient to overcome balance of payments problems. They often need to be supplemented by foreign currency controls and discretionary allocation of foreign exchange, as was the case in industrial countries during the post-war period and which remain necessary in a number of developing countries. Thus, trade liberalisation programmes normally include dismantling of exchange controls, which has direct consequences for the management of the capital account.

But even where exchange controls are not a factor, there is another mechanism through which the capital account is affected. The proposition that trade policy may not affect the trade balance is contingent on the exchange rate being allowed to adjust appropriately to changes in import barriers. The removal of trade barriers would obviously increase imports, but this is precisely what is required to make domestic industry internationally competitive. However, exports can also be expected to rise if

${ }^{2}$ Foreign currency accounts were popular also because the government promised not to ask any questions as to the source of money. Thus, people with "black money" could convert them into US dollars at the kerb market, and deposit them into foreign currency accounts. After the explosion of the nuclear bomb in May 1998, these accounts were, however, frozen. They could thereafter only be converted into Pak rupees at the specified official rate. 
the currency depreciates to compensate for the removal of trade barriers. Trade liberalisation programmes do, however, anticipate temporary rise in trade deficits as the economy adjusts to the new situation, which provides the rationale for lending by the international financial institutions in support of the policy reforms.

There are, however, practical and theoretical difficulties in accepting the notion that the trade balance will remain more or less unaffected by the removal of trade barriers because of exchange rate adjustments. The actual experience in developing countries has been one of generally rising and persisting trade deficits consequent to trade liberalisation. UNCTAD (1999) reports a general rise in trade deficits as a proportion of GDP even as economic growth in developing countries decelerated over the last decade, a period marked by a general lowering of trade barriers by the developing countries. This trend held across different regions and countries. Mexico, for example, experienced dramatically rising imports, without commensurate increase in exports, after trade liberalisation both during the late 1970s and late 1980s. Thailand, Indonesia, Ghana, and many other countries, also experienced a sharp worsening of the trade balance.

Why exports fail to rise, contrary to what the theory predicts, has several explanations. For one thing, it is generally a mistake to hold price as the principal reason for stagnant export earnings. Exchange rate can certainly be a handicap for exporters, but it is not usually the only, or even the most important factor discouraging export activities. More fundamental reasons tend to be poor physical infrastructure, difficulties in obtaining trade finance, neglected and obsolete capital equipment, lack of skilled manpower and technological capabilities, and so on. A depreciated exchange rate, for example, can hardly compensate for the lack of transportation or electricity. In such situations, "getting the prices right" is a very ambiguous, if not meaningless, slogan. It is rather recently that the World Bank has started to be concerned about the supply-side hindrances to exports.

But even if such problems did not exist, exchange rate changes may not be sufficient to bring about the required adjustment in the trade balance. A devaluation, if it is to work, must shift the relative prices in favour of traded goods and their domestic substitutes, the so-called "tradables", and against sectors which normally are not open to trade, the "nontradables". ${ }^{4}$ There is, however, no certainty that such a price shift

\footnotetext{
${ }^{3}$ International financial institutions have had to face the awkward question of why they need to provide finance in support of policy reforms that are supposed to be in the interest of the country concerned.

${ }^{4}$ The distinction between tradables and nontradables in reality is not sharp. It is more accurate to rank economic activities on the basis of the ease of their being internationally
} 
would in fact occur or be sustained over a period of time. If nontradables are more capital intensive than tradables, a devaluation can have a perverse effect on relative prices, i.e., prices of nontradables could rise relative to tradables (Rahim 1998). In any case, if labour has the bargaining power, it may undo the impact of a devaluation by not accepting an erosion of real wages.

A more crucial point, however, is that the shift in relative prices by itself is not sufficient to bring about an improvement in the trade balance. The reason is that while the price shift in favour of tradables encourages domestic production and discourages domestic consumption of the tradables, it has precisely the opposite impact on the nontradables. This creates an untenable situation, for, while foreign trade can make up the difference between the demand and supply of tradables, no such possibility exists in the case of the nontradables. The market for nontradables, by definition, requires that domestic demand equal domestic supply. The equilibrium can then only be restored if either the overall economic activity is reduced so that the excess demand for the nontradables is reduced through the income effect, or prices of the nontradables are allowed to rise to choke off the excess demand. In the first case, there is an overall reduction in domestic economic activity, though the trade balance may improve. An improvement, however, could not materialise if prices of nontradables rise, undoing the initial shift in relative prices. The net effect in this case would simply be an acceleration of inflation.

It is for all these reasons, countries resorting to devaluation are usually required to adopt restrictive fiscal and monetary policies (what the IMF calls "demand management policies"). Demand compressing deflationary measures may be justified when an economy is over-heated, with a tight labour market and constrained physical productive capacity. But in situations where the economy has experienced declining output or stagnation-as has been the case in many developing countries and transition economiespolicies requiring further economic contraction can hardly be considered optimal. They have been found time and again to contribute to economic instability.

The alternative of allowing inflation to accelerate may also not be very attractive to governments that have brought down inflation with difficulty and wish to keep it low. Mexico, during the period leading up to the 1994 financial crisis, faced a common policy dilemma. Long before the

traded. The dramatic reduction in transportation and communication costs over time has led to international trade in an increasing number of goods and services, thus reducing the size of what could be considered as purely domestic activities. 
actual crisis, it had become apparent that Mexico's large trade deficit (amounting to 6-8 per cent of GDP) could not be sustained indefinitely. The financial crisis was blamed on the government's failure to devalue the peso early enough. However, the government was reluctant to risk fuelling inflation or to allow a decline in economic activity. Having been applauded by the international financial community for bringing down the inflation, the government feared adverse investor reaction if signs of renewed inflation reappeared. At the same time, and partly because of the fight against inflation, there was little scope for demand compression because the economy had shown little vigour over the years. Private fixed investment had remained hesitant and economic growth at best modest.'

The question then arises as to how governments should cope with enlarged trade deficits if they cannot, for one or another reason, rely on the exchange rate. Foreign exchange reserves are of course finite, and can only be of temporary help in dealing with balance of payments problems. This then leaves borrowing from abroad as the only option. Foreign lending, however, is contingent on several factors, including, of course, the country's creditworthiness. However, in the general atmosphere of market liberalism of the last two decades, an important consideration in both official and private lending has been the borrower's commitment to free-market principles. As noted earlier, the official bilateral and multilateral lenders were eager to see rapid adoption of market reforms, covering trade, capital markets, and privatisation in the developing countries. Private lenders were also happy with these changes because they offered new opportunities for making quick profits, with repatriation of capital and earnings more or less assured, the exchange rate risk notwithstanding.

In short, relaxation of controls on the access to foreign currencies and foreign borrowing becomes necessary when trade liberalisation results in trade deficits that cannot be corrected by means of an exchange rate adjustment. The situation is in some respects analogous to trade within a single country: free movement of goods and services would be inconceivable without a unified financial system that allows trade deficit regions to borrow from trade surplus regions. There are of course limits to borrowing and individual regions of a country can experience "balance of payments" problems if they continue to overspend (as is evident from the experience of different municipalities and states in the United States over the years). The important point, however, is that free trade is difficult if there is no access to credit.

\footnotetext{
${ }^{5}$ Although the situation is fundamentally different, the United States too, with its large trade deficit, faces today a dilemma: a depreciation of the dollar could trigger a general loss of confidence, without an assurance that it would improve the country's trade balance.
} 


\section{The Case for Trade Policy Interventions}

The basic rationale for trade liberalisation (and free movement of capital $)^{6}$ is that it leads to optimal consumer and producer decisions. Price signals, in the absence of government interventions, are held to reflect real costs of goods and factors of production. Guided by free market prices, consumers and producers make choices that, in theory, lead to the so-called Pareto optimal situations, i.e., where no one can be made better off without making someone else worse off. This basic proposition, also called the "fundamental theorem of welfare economics" (Stiglitz 1994), has had an extremely powerful influence in the evolution of mainstream economics. Sure enough, the possibility that market prices may not reflect true social costs has been recognised and has provided the justification for government interventions. But the dominant view over the last two decades has been that market failures are either not very important or not as serious in their economic consequences as government failures. The proponents of freemarket principles hold that government action as a remedy is worse than the problem of market failure itself.

There are certainly situations where general opening up of the economy and deregulation can be highly beneficial. In countries where protectionism amounts virtually to autarky-as it did, for example, in the former Soviet Bloc countries-productive inefficiency and internationally non-competitive industries can be a serious problem. It is easy to visualise that the gains from protection at some point begin to fall short of the cost of foregone trade opportunities. Apart from providing goods that the country can either not produce or produce only at a high cost, foreign trade is a major vehicle for the transfer of ideas and technological knowledge. It also provides the competitive pressure for improving productive efficiency.

There are also many countries which, while not autarkic, have poorly designed government controls and regulations that are difficult to enforce. These only hurt productive enterprise and creativity, and encourage expenditure of time, money, and talent to circumventing them. It is also common to find overlapping or redundant restrictions on foreign trade; for example, high import duties coexisting with non-binding import quotas or licensing requirements. In all such situations, deregulation, liberalisation, and general rationalisation of public policy can be expected to enhance productive efficiency. China and India, while retaining considerable control

\footnotetext{
${ }^{6}$ The proponents of free capital mobility keep conspicuously silent about the benefits from labour mobility. One excuse sometimes offered for this omission is that free capital movement renders the movement of labour unnecessary.
} 
and regulation over trade and capital movements, have benefited from such market liberalising measures and realised accelerated economic growth.

The proponents of free trade, however, tend to oversell the case for trade liberalisation. The fact is that trade policy continues to be widely employed in both industrial and developing countries for all sorts of reasons. There is hardly a country that did not rely on some form of protection to promote its industry. It is now widely acknowledged that trade policy interventions were particularly significant in the development strategies of the East Asian economies, including Japan. ${ }^{7}$ This is an important point, for the proponents of trade liberalisation do not generally concede any merit in protection. Anything short of totally free trade implies that some trade policy interventions may indeed be socially beneficial. There was some interest in the early 1980s in constructing formal trade models to define situations where trade policy interventions might indeed be optimal. However, these forays in advance theory (which came to be called "strategic trade theory") were seen to be so threatening to the ruling orthodoxy that the proponents themselves took great pains to stress the limited practical usefulness of their work. ${ }^{8}$

The reasons for continuing support for protectionist measures are both theoretical and practical. For one thing, the neoclassical model of comparative advantage on which the case for free trade rests is highly restrictive. Free trade may not be optimal in situations where the comparative advantage cannot be taken as given (as in the conventional theory), but is being deliberately created in new economic activities through capital accumulation and development of technological capabilities (Haque $1995)$.

There is extensive literature-ranging from Alexander Hamilton, von Mises, to present-day protagonists-that argues for judicious protection to foster industrial development. Market failures in the promotion of infant industry are widely acknowledged, but there is no meeting of the minds on whether trade restrictions are suitable to deal with these failures. Neoclassical economists argue against protection on grounds that it leads to unproductive "rent-seeking" (i.e., corruption) and that it is more efficient to deal with market failures at their source (see, for example, Bhagwati 1989). In other words, rather than resorting to import controls, it is more efficient

\footnotetext{
${ }^{7}$ The literature on this is extensive. See, in particular, Wade (1994), Amsden (1989), and the World Bank (1993).

${ }^{8}$ Krugman (1987) reflects well the tension between the economist's firm belief in the virtues of free trade and his theoretical insights that point the other way.
} 
to compensate producers through subsidies to overcome specific problems, such as poor infrastructure or lack of skilled manpower, etc.

Even if market failures are best dealt with at source, it is often not feasible to do so in practice, especially because of the difficulties in raising revenue to pay for subsidies. Transparency in public policy is certainly a worthy goal, but keeping the identity of losers ambiguous is part of practical politics. The political and practical convenience is probably a major reason why virtually all governments adopt trade policy measures to placate domestic interests and penalise foreign suppliers. The argument that such means are economically irrational has obviously not made much impact on, for example, trade restrictions in textiles or agriculture in the industrial countries.

The market failure argument, however, is anchored in the assumption of perfectly competitive markets of neo-classical economics. If markets in reality never conform to the theory, the way they actually function cannot be called a "failure". There are indeed other considerations that necessitate resort to trade policy interventions. The difficulty in managing the balance of payments problems exclusively through exchange rate adjustment has already been discussed. The rules under GATT (now World Trade Organisation) allow for trade policy interventions to overcome balance of payments difficulties. GATT Rule XII, entitled "Restrictions to Safeguard the Balance of Payments", permitted any country to impose import restrictions when the threat to the balance of payments is "imminent" and the country's foreign exchange reserves are "very low". The rules on import restrictions are rather more lenient for developing countries, which can invoke them even when a serious decline in their reserves has not actually occurred but is only foreseen. The rationale is that import restrictions are likely to be less harmful for the world trading environment than the alternative of serious recession brought on by balance of payments problems.

Trade policy interventions also become necessary when producers' economic and financial strength differs widely. Big firms enjoy certain advantages (for example, in distribution costs, conduct of R\&D, mobilising finance, advertising, and, not least, in the exercise of political influence) over small firms. ' The survival in the real world does not so much depend on being efficient in production as on the firm's size. It is usually the bigger firm that takes over the small, rather than the more efficient taking over the less efficient. By virtue of being small, producers in developing countries,

${ }^{9}$ This is not to deny that small firms do enjoy advantages of flexibility and better responsiveness to consumer tastes, and in some lines of economic activity, these are the determinants of success. 
therefore, face a significant handicap in competing in the world market over producers in developed countries. When size is the determinant of commercial success, competitive pressure may not yield improved productive efficiency. Just as in the world of sports, competition in world commerce requires some recognition being given to the inherent handicaps that developing countries suffer from.

Predatory pricing-i.e. aggressively lowering prices to oust a competitor-is another consequence associated with the firm size and, despite the legal penalties, is a common phenomenon in industrial countries (Baumo1 1993). In developing countries, allegations of predatory pricing by foreign firms that deters the rise of domestic industry are common. ${ }^{10}$ This could, in principle, be taken up under the WTO's anti-dumping rules, but legal recourse against the predator is difficult if the injured party cannot be produced in the court. In all such situations, restrictions on imports seem to be the only means available to promote domestic industry.

In conclusion, two further points need to be made. First, just as the opening up of capital account requires satisfaction of prior conditions, there is also a need for careful preparation before a country undertakes trade liberalisation. Certainly, industrial countries have not rushed into trade liberalisation. It has taken a series of rounds of multilateral trade negotiations-spanning a period of nearly half a century-to bring down protection to the current levels. Even so, many products of interest to developing countries continue to face high tariffs and non-tariff barriers (UNCTAD 1999). After three decades of special rules governing trade in textiles, industrial countries feel unable to face unhindered competition from textile suppliers in developing countries. At the same time, agricultural protection remains strong. There has also been frequent use of the so-called voluntary export restraints (VERs) by the United States, EU countries, and others in order to permit their domestic industries to become internationally competitive.

The problems that face developing countries are, of course, much more serious. Stiglitz (1998) observes that there was not sufficient preparation in a number of developing countries and that trade liberalisation was often seen as a goal in itself, rather than a means to an end. In situations where domestic production suffered from basic structural weaknesses of physical infrastructure, lack of technological depth, domestic competitive environment, an increased exposure to foreign competition could not realistically be expected to bring about improvements in

\footnotetext{
${ }^{10}$ There are also situations where the opposite is the case. To counter a situation where developing countries are being charged a higher price, "anti-collusion duties" have been recommended by some. (See, for example, Whalley 1999)
} 
productive efficiency. On the contrary. In a large number of developing countries, premature trade liberalisation considerably weakened, if not destroyed altogether, the existing industry.

Secondly, there is increasing evidence that, in arguing for free trade, the proponents have tended to exaggerate the benefits from liberalising trade. Several years ago, Dornbusch (1992) noted:

"Although the discussion of trade policy at times gives the impression that a liberal trade regime can do wonders for a country's economy, and most observers believe firmly that trade reform is beneficial, yet systematic attempts at quantification fail to single out trade policy as a major factor in economic growth" (p. 73).

More recently, Rodrik (1999) reports that there is little or no relationship between growth rates and indicators of openness, i.e., levels of tariff and non-tariff barriers or controls on capital flows.

The practical implications of this empirical conclusion are important. For one thing, it implies that the harm that is alleged to be caused by protectionist policies in developing economies is exaggerated. For another, even if protection may not be the first best policy, it could very well be usefully employed since its costs are not as high as they were earlier believed to be. But it needs to be stressed that acknowledging a role for trade policy does not imply support for beggar-thy-neighbour policies of mounting protection and competitive devaluations of the type that the industrial countries pursued during the inter-war period.

\section{The Exchange Rate Question}

If currency markets behaved like ordinary markets, the interaction of demand and supply of currencies could be expected to yield the equilibrium value of the exchange rate. But currency markets are notorious for their volatility. A major reason for it is the dominant role of expectations concerning policies and outcomes not only within the country concerned but also in other countries. The exchange rate is intrinsically what links economic policies of one country with the others'. Governments intervene to stabilise currency values from time to time, but with limited success. In situations of panics and currency runs, such attempts are almost always futile because the available foreign exchange reserves are simply never enough to counter what amounts to speculators' one-way bets. When the chance of a currency depreciating is infinitely greater than its appreciating, speculation against the currency can hardly be contained. 
Considering the common experience of currency collapses leading to precipitous declines in national output-most dramatically shown by the East Asian crisis-the costs of exchange rate instability are arguably worse than trade policy interventions. But currency instability and unpredictability also distorts decision-making, not too differently from tariffs and other protectionist devices. The traditional theory of comparative advantage relates strictly to the real economy, where the basis of specialisation in international trade is solely the relative costs of production. The value of currencies as such plays no role. However, the exchange rate, through its impact on real wages, has a differential impact on the profitability of different economic activities. In the specific case of an exchange rate depreciation, the consequent reduction in real wages can be expected to make the relatively labour-intensive sectors more profitable, and vice versa in the case of an appreciation. It is fairly common that relatively moderate exchange rate shifts turn perfectly successful enterprises into loss-making. In other words, exchange rate instability can upset the basis of specialisation and jeopardise the advantage of free trade. Competitive devaluations of the inter-war period were as much to blame for the disruption of international trade as direct trade barriers.

But exchange rate instability also distorts investment decisions across countries. With exchange rates hard to predict, private investors' concern is primarily the financial return, which bears little relation to the real return. This falsifies the basic premise that free international capital flows maximise the return on investment globally, and hence lead to an overall improvement in resource use. The pursuit of financial returns, far from allocating capital efficiently across countries, tends to make investment decisions short-sighted, while unstable exchange rates discourage long-term productive investment (Davidson 1998).

In short, there is a real conundrum here. The stability of the exchange rate is central to realising the putative benefits from free trade and capital mobility (i.e., improved resource allocation across sectors and countries), but, as we saw earlier, unregulated trade and capital movements also tend to make the exchange rate unstable and difficult to manage. The architects of the Bretton Woods system that was instituted after the Second World War visualised exchange rate stability as pivotal to ensuring harmonious trading relations and responsible macroeconomic policy by individual countries. But the regime of fixed rates broke down in 1972, and the world entered an era of fluctuating exchange rates and disturbed currency markets. ${ }^{11}$ The European Union also found that proper economic

\footnotetext{
${ }^{11}$ The proponents of flexible exchange rates base their case largely on the impracticality of maintaining fixed rates in situations where countries pursue independent monetary and
} 
integration required a certain degree of currency stability, at least among the major member economies. This was tried under various monetary arrangements over the years, but, ultimately, it had to opt for a single currency, the euro, which required member countries surrendering their autonomy in monetary policy.

A few economies (notably, Argentina and Hong Kong) have stabilised their currencies by opting for currency boards that require holding foreign exchange reserves almost equal to money supply. This system has proved to be very costly, not just because large liquid reserves have to be maintained, but also because of the consequences of having to abandon independence in formulating macroeconomic policy. Argentina continues to pay a heavy price of fixing its exchange rate in terms of lost output and high unemployment. The experience of Hong Kong has shown that despite enormous foreign exchange reserves, a currency board system does not protect an economy from speculative runs on the capital market.

There are then the proposals for instituting some mechanisms for impeding short-term capital flows in order to preserve economic and financial stability. The proposal for the so-called Tobin tax is more than two decades old, but is generally considered to be difficult to implement. Chile's tax on short-term capital inflows received considerable interest recently, but it could not stop speculative outflows, as Chile discovered to its embarrassment in the aftermath of the East Asian crisis. In any case, it seems doubtful that simply restricting short-term capital flows is likely to prevent currency crises. Britain, for example, felt threatened by the "gnomes of Zurich" at a time when capital flows across countries were much more restricted. Today, the situation is complicated by the introduction of new financial instruments, such as hedge funds and derivatives, that have rendered the distinction between the short and long term finance rather tenuous. Countries that cannot get long term finance on acceptable terms will resort to short-term borrowing, though there are devices to cover up the fact. In any case, so long as there is a market for long-term bonds and securities, controlling simply short-term capital flows can hardly be expected to stabilise currency markets.

There are various reasons why it has been difficult to devise a system of stable exchange rates, short of a complete monetary union. To start with, it is extremely difficult-and often imprudent-for countries to give up their autonomy in formulating macroeconomic policy. Countries' needs for

fiscal policies. They do not, I think, dispute the desirability of fixed rates from the point of view of optimal decision-making. Milton Friedman is reported to have said that he favoured flexible exchange rates provided they did not change. 
generating growth and employment differ, according to their stage of economic development or phase in the business cycle. Economies that aim to grow fast and catch up with the higher-income economies need macroeconomic policies that may not conform to some externally dictated format. With regard to business cycles, despite the rise in international trade and capital mobility, the different phases do not quite coincide even among the industrial economies.

There is also the problem of determining the "right" rate for an economy, which is not only a politically controversial matter (as it affects different groups differently), it also leaves professional economists debating among themselves. ${ }^{12}$ Even when the capital account is closed, there is usually no stable and unique relationship between the exchange rate and the trade deficit. For this to be possible, there must, in fact, exist two sets of stable one-to-one relationships: one, between the trade balance and the real exchange rate (i.e., it should be possible to associate a certain real rate with a given trade balance); and, two, between the nominal and the real rate (i.e., it should be possible to influence the real rate in a predetermined direction by means of an adjustment in the nominal rate, the only lever that the government can pull). This can seldom be achieved in reality. As noted earlier, there is not, generally speaking, a one-to-one relationship between the real rate and the trade balance because of the likelihood of disequilibrium in the market of nontradables. The latter dictates some adjustment in domestic absorption. Similarly, the impact of the nominal rate on the real rate is also far from straightforward, dependent as it is on the responses of workers and producers of nontradables.

When capital can move across countries more or less unhindered, perverse movements in the exchange rate are fairly common. There has been considerable debate on whether destabilising speculation can be profitable, and therefore something that the private sector would tend to shun over the long term. Whatever the merits of this proposition, the fact is that the world has witnessed a series of currency crises since the breakdown of the Bretton Woods system in the early 1970s. The typical scenario has been that, on the upswing, capital moves into economies in search of profit, leading to exchange rate appreciation and a ready-made payoff on foreign investment. The opposite happens when there is an outflow of capital that leads to runs on currencies.

\footnotetext{
${ }^{12}$ The problem is not one of knowing when the rate is wrong but of determining the right rate. Situations where the exchange rate is totally misaligned are not difficult to identify. If a country has had a much higher inflation than its trading partners over a run of years, a devaluation would become inevitable at some stage, though the extent to which the currency had become overvalued could be a matter of debate.
} 
Finally, the problem is that in an open economy the "right" exchange rate is almost impossible to determine: capital account considerations may pull the exchange rate in one direction, while the imperative of restoring trade balance may point in the other. It has been observed time and again that high interest rates, which may be dictated by domestic macroeconomic considerations, attract foreign capital, which in turn put pressure on the domestic currency to appreciate. But this erodes the country's competitiveness in exports and import-substituting activities vis-à-vis foreign producers. The US economy is currently faced with this kind of situation. A stable dollar is required in order to keep attracting foreign finance, which is needed to finance the large trade deficit. But the trade deficit itself feeds the expectations that the dollar will have to come down.

The question of policy boils down basically to a choice between fixed rate, but with externally enforced monetary policy, and flexible rates, with individual countries retaining their policy autonomy. In order for markets to be free and well-functioning, and to reap the benefits of international specialisation and free movement of capital, some means of mimicking a single currency area, with fixed exchange rates, becomes essential. In other words, there is a need to recreate conditions for free movement of goods and factors similar to those that prevail within a single economy so that producers and consumers base their decisions on prices undistorted by exchange rate movements. Alternatively, countries may pursue independent macroeconomic policy to achieve national objectives along with flexible exchange rates. But in order to prevent exchange rate flexibility from turning into volatility, governments need to exercise a measure of control over both current and capital accounts. ${ }^{13}$ The first option is an extreme variant of market liberalism, and there may be some efficiency gains of the kind enlarged trading areas experience. However, so long as countries remain at very different stages of economic development and economic well-being, governments will continue to be pressured by their constituents for independent national policies.

\section{Summing-up}

This note attempted to show that trade liberalisation and measures to open up the capital account that a number of countries undertook in recent years were intimately linked. They were both driven by the same ideological tide of market liberalism that has been highly influential in

\footnotetext{
${ }^{13}$ In a recent article on the problem of US trade deficit and exchange rate management, Ron McKinnon (1999) notes: "A commercial agreement between the United States and Japan is a necessary condition for a credible exchange-rate accord.” (p. 79)
} 
industrial as well as developing economies during the last two decades. While the case for regulating capital flows is robust, there is a need also to recognise the need for regulating trade flows. There are two reasons for this. One, international trade, just as capital mobility across countries, suffers from market failures and other problems, which justify government intervention. And, two, it is unlikely that, in situations where trade deficits are worsening, simply controlling the movement of short-term capital would stabilise currency markets. There are real problems of financing trade deficits that also need to be dealt with.

Free trade and mobility of capital across countries offer certain benefits, at least in theory, but they also make countries vulnerable to financial crises. This risk could be avoided if it was possible to institute a regime of fixed exchange rates, along with the concomitant requirement of individual countries surrendering their macroeconomic policy to a supranational central authority. This obviously cannot be undertaken by any single country, but requires international action. This issue should, therefore, be a central concern in the reform of the international financial and monetary system. Alternatively, the current system of flexible exchange rates could continue along with the freedom to design macroeconomic policy that suits individual countries. However, this system will remain prone to currency crises, unless both capital movements and trade are regulated. In brief, countries can either opt for liberal trade regimes and free capital markets but with fixed exchange rates, leaving the fate of their economies in the hands of an outside agency, or choose to retain independent macroeconomic policy with flexible exchange rates, which are kept within manageable bounds by means of trade policy as well as restraints on capital flows.

It is, in the end, basically pragmatic policies, rather than a blind faith in an ideology, that can ensure economic stability and growth. Unfortunately, the argument for free trade, as for free movement of capital, remains anchored in an idealised world that is far removed from the everyday reality. Policies need to be crafted within a given political and economic context. The fact that trade policy gives rise to problems is no more ground for discarding it than is the case for abandoning income tax for its general abuse and social and economic complexities. This is not to deny that a number of developing countries could benefit from a rationalisation of their trade policy, which may in fact entail generally lower trade barriers. 


\section{References}

Amsden, Alice. 1989. Asia's Next Giant: South Korea and Late Industrialization. New York: Oxford University Press.

Baumol, William J. 1993. Entrepreneurship, Management, and the Structure of Payoffs. Cambridge, Massachusetts: The MIT Press.

Bhagwati, Jagdish. 1989. "Is Free Trade Passé After All?" Weltwirtschaftliches Archiv 125: 17-44.

Bhagwati, Jagdish. 1998. "The Capital Myth-The Difference between Trade in Widgets and Dollars". Foreign Affairs. Vol. 77, No. 3. 7-12.

Davidson, Pau1. 1998. “The Case for Regulating International Capital Flows”. University of Tennessee. Paper presented at the Social Market Foundation Seminar on Regulation of International Capital Flows", London, 17 November, 1998.

Krugman, Paul. 1987. “Is Free Trade Passé?” Journal of Economic Perspectives. 1 (2): 131-46.

Krugman, Paul. 1998. "Saving Asia: It's Time to Get Radical”. Fortune. September 7, 1998.

McKinnon, Ronald. 1999. "Wading in the Yen Trap". The Economist. July 24, 1999.

Rahim, Sikander. 1998. "The Exchange Rate and Its Effects". The Labore Journal of Economics. Lahore School of Economics. December 1998. Vol. 3. No. 2.

Rodrik, Dani. 1998. "Who Needs Capital Account Convertibility?" Mimeo, February 1998. A contribution to a symposium edited by Peter Kenen, to be published as Essays in International Finance, Princeton University Press.

Rodrik, Dani. 1999. "The New Global Economy and Developing Countries: Making Openness Work." Overseas Development Council, Washington D.C.

Sachs, Jeffrey. 1998. "Global Capitalism: Making it Work”. The Economist. September 1998. 
Stiglitz, Joseph E. 1994. Whither Socialism? Cambridge, Massachusettes: MIT Press.

Stiglitz, Joseph E. 1998a. "More Instruments and Broader Goals: Moving Toward the Post-Washington Consensus." WIDER Annual Lectures 2. January 1998. The United Nations University: World Institute for Development Economics Research.

Stiglitz, Joseph E. 1998b. "Boats, Planes, and Capital Flows". Financial Times. March 25, 1998.

UNCTAD. 1999. Trade and Development Report, 1999. United Nations. New York and Geneva.

Wade, Robert. 1990. Governing the Market: Economic Theory and the Role of Government in East Asian Industrialization. Princeton: Princeton University Press.

Whalley, John. 1999. "Special and Differential Treatment in the Millennium Round”. CSGR Working Paper No. 30/99. May 1999. Economic and Social Research Council. The University of Warwick, U.K.

Wolf, Martin. 1998. “Capital Punishment”. Financial Times. March 17, 1998.

World Bank. 1993. The East Asian Miracle: Economic Growth and Public Policy. Oxford: Oxford University Press for the World Bank. 